\title{
Menemukan Kesejahteraan Psikologis Dibalik Profesi Dosen: Psychological Contract sebagai Salah Satu Prediktor Tercapainya Psychological Well Being pada Dosen
}

\author{
Rezki Ashriyana Sulistiobudi*1, Anissa Lestari Kadiyono² ${ }^{2}$, Megawati Batubara ${ }^{3}$ \\ ${ }^{1-3}$ Fakultas Psikologi, Universitas Padjadjaran \\ Jl. Raya Bandung- Sumedang Km 21, Jatinangor - Sumedang 43363 \\ *rezki.ashriyana@unpad.ac.id
}

\begin{abstract}
This study aims to determine how the influence of the psychological contract on the psychological well-being of lecturers in educational institutions. The psychological contract is formed on the belief that the organization's employees will appreciate the contribution and to meet expectations. This belief will create positive work experiences and form a psychological sense of security. The realization of the psychological contract can bring balance and harmony at employees in the work, optimizing organizational productivity, building a good relationship between the employee and the organization, and minimize conflict and social inequality in organization. This condition is identical to the psychological well-being. The results showed that there is a significant relationship between psychological contract and psychological wellbeing. Low gap both of transactional and relational contract means that psychological contract breach is in the low level. The lower level of breach felt by the lecturer is the more they have high level of psychological wellbeing. It will have an impact on increasing positive feelings of the individual. Lecturers who perceive that personal growth and personal life provide the greatest contribution of their wellbeing.
\end{abstract}

Keywords : lecturer, psychological contract, psychological well-being

\begin{abstract}
Abstrak
Penelitian ini bertujuan untuk mengetahui bagaimana pengaruh kontrak psikologis terhadap kesejahteraan psikologis pada tenaga pendidik di institusi pendidikan. Hubungan timbal balik atau kontrak psikologis terbentuk dari keyakinan karyawan bahwa organisasi akan menghargai kontribusi dan memenuhi harapannya. Keyakinan ini akan menciptakan pengalaman kerja yang positif dan membentuk rasa aman secara psikologis. Terwujudnya kontrak psikologis dapat memunculkan keseimbangan, keselarasan, keserasian, kelancaran karyawan dalam bekerja, kemajuan organisasi, hubungan yang baik antara karyawan dan organisasi, serta meminimalisir munculnya konflik dan kesenjangan sosial. Kondisi ini identik dengan kesejahteraan psikologis. Hasil penelitian menunjukkan bahwa terdapat hubungan yang signifikan antara psychological contract dan psychological well being. Rendahnya gap antara kebutuhan dan pemenuhan baik pada transactional dan relational contract bermakna rendahnya psychological contract breach yang dirasakan oleh dosen. Semakin rendah tingkat pengingkaran yang dirasakan maka akan semakin tinggi tingkat psychological well
\end{abstract}


being mereka. Hal ini akan berdampak pada peningkatan perasaan yang lebih positif. Dosen merasa bahwa faktor personal growth dan personal life lah yang memberikan kontribusi terbesar terhadap kesejahteraan psikologis mereka.

Kata Kunci : dosen, psychological contract, psychological well-being

\section{Pendahuluan}

Pentingnya peranan sumber daya manusia dalam sebuah organisasi membuat organisasi perlu menjaga hubungan yang positif dengan karyawan. Hubungan karyawan dengan organisasi sangat penting untuk keberhasilan suatu perusahaan karena dapat menentukan motivasi dan dedikasi karyawan, keterikatan kepada perusahaan dan komitmen organisasi (Coyle-Shapiro, Taylor, Shore and Tetrick, dalam Aggarwal, U \& Bhargava, S, 2010). Hubungan karyawan dan organisasi pada dasarnya adalah kontrak pertukaran sumberdaya antara dua pihak yaitu karyawan dan perusahaan (Aggarwal \& D'Souza K.C, 2012). Hal-hal tersebut dioptimalkan untuk dapat memaksimalkan unjuk kerja karyawan.

Kedua pihak ini terikat dalam kesepakatan sebagai hasil dari persepsi mengenai kewajiban dan pemenuhannya oleh institusi yang disebut dengan psychological contract (kontrak psikologis). Kontrak ini membentuk interaksi diantara kedua belah pihak yang dapat mempengaruhi produktivitas dan performansi kerja. Kontrak psikologis merupakan keseluruhan dari harapan baik tertulis maupun tidak tertulis, terucap atau tidak terucap antara organisasi dengan karyawannya. Harapan-harapan ini berkaitan dengan kinerja kerja, keahlian tertentu, hubungan sosial, penghargaan dan sebagainya.

Rousseau (1995) mendefinisikan kontrak psikologis sebagai keyakinan mengenai syarat dan ketentuan pertukaran kesepakatan secara timbal balik antara individu dan organisasi. Sementara itu, Kotter (dalam Aggarwal U \& D'Souza, 2012) mendefinisikan kontrak psikologis sebagai keyakinan karyawan, yang berdasarkan janji yang diekspresikan, berdasarkan pertukaran kesepakatan antara individu dengan organisasi. Pengertian dari Guest (dalam Lee Hung-Wen, Liu Ching-Hsiang, 2009) menyatakan bahwa pada dasarnya, kontrak psikologis merupakan pengharapan timbal balik antara dua pihak. Maka dapat disimpulkan bahwa kontrak psikologis merupakan sebuah filosofi hubungan kerja mengenai pengharapan timbal balik antara karyawan dan organisasi mengenai apa yang menjadi kewajiban dan apa yang akan diberikan sebagai timbal balik satu sama lain.

Seiring berjalannya waktu, kontrak psikologis dapat berubah sesuai dengan kondisi kerja, pengalaman dan perusahaan. Armstrong (2007) menyatakan bahwa karyawan berharap diperlakukan adil sebagai manusia, diberikan pekerjaan yang menggunakan kemampuan mereka, diberikan balas jasa yang setimpal dengan kontribusi mereka, dapat berkembang dan menunjukkan kompetensi, memiliki peluang untuk tumbuh lebih lanjut, mengetahui apa yang diharapkan dari mereka dan diberikan umpan balik mengenai bagaimana pekerjaan mereka. Sementara itu, dari sisi perusahaan berharap karyawan memberi kinerja terbaik mereka atas nama organisasi, berkomitmen sepenuhnya terhadap nilai-nilai perusahaan, rela dan loyal, serta meningkatkan kualitas perusahaan. Dari hal ini terlihat bahwa masing-masing pihak, baik individu maupun organisasi memiliki kepentingan yang berbeda-beda, yang tentunya akan mempengaruhi pembentukan kontrak psikologisnya. 
Hal ini sejalan dengan pernyataan Griffin dan Moorhead (2010) yang menjelaskan konsep dasar hubungan pertukaran kontrak psikologis (Griffin dan Moorhead, 2010), bahwa individu akan memberikan kontribusi untuk organisasi melalui usaha, kemampuan, keahlian, waktu dan loyalitas. Sebagai ganti untuk kontribusi tersebut, organisasi memberikan dorongan untuk karyawanseperti gaji, peluang karir,job security, dan status. Dengan kata lain, individu memiliki pengharapan tertentu pada organisasi untuk memberikan timbal balik yang sesuai dengan kontribusi yang ia berikan.

Terpenuhinya harapan karyawan dapat mengindikasikan bahwa kontrak psikologis terwujud dengan baik. Kondisi ini akan memunculkan keseimbangan, keselarasan, keserasian, kelancaran karyawan dalam bekerja, kemajuan organisasi serta hubungan antara karyawan dengan organisasi. Kontrak psikologis yang kuat dapat pula berfungsi untuk menghindari munculnya konflik dan kesenjangan sosial antara organisasi dengan karyawan. Kondisi tersebut identik dengan kesejahteraan psikologis, atau dapat disebut dengan psychological well-being. Seseorang dapat dikatakan memiliki kesejahteraan psikologis ketika dapat berfungsi positif secara psikologis, memperoleh kebahagiaan, kepuasan hidup dan tidak adanya gejala-gejala depresi (Bradburn, M, 1969; Ryff, D, 1989). Individu yang memiliki kesejahteraan lebih tinggi akan lebih produktif dan memiliki kesejahteraan mental serta fisik yang lebih baik dibandingkan dengan yang kesejahteraannya rendah (Ryff, D \& Singer, K, 2006).

Terbentuknya kesejahteraan psikologis dipengaruhi oleh adanya persepsi karyawan terhadap pemenuhan harapan yang diberikan organisasi. Persepsi ini merujuk pada keyakinan karyawan mengenai sejauh mana organisasi menghargai kontribusi dan kepedulian terhadap kesejahteraan karyawan (Eisenberger, Huntington, Hutchison, \& Sowa 1986). Karyawan yang merasa telah memberikan kontribusi yang baik, memiliki keyakinan mendapatkan imbalan yang sesuai dengan kontribusi yang diberikannya. Keyakinan karyawan terhadap organisasi, bahwa organisasi akan memenuhi harapannya akan menciptakan pengalaman kerja yang positif dan merupakan suatu bentuk perasaan rasa aman secara psikologis pada diri karyawan. Whyte (1956) mengatakan salah satu aspek dalam pemenuhan kontrak psikologis adalah dengan terpenuhinya kebutuhan akan rasa aman. Beberapa penelitian lainnya menunjukkan bahwa pengalaman kerja yang positif mempengaruhi kesejahteraan psikologis individu (Ryff \& Singer, 2006).

Berdasarkan paparan diatas, sudah sangat banyak penelitian psychological contract di lingkup karyawan dan perusahaan, namun masih terbatas yang membahas pada dosen sebagai tenaga pendidik di perguruan tinggi. Kini peran dosen sudah mulai bergeser menjadi lebih kompleks seiring dengan perubahan tuntutan dunia pendidikan yang semula agent of education kini menjadi agent of culture, knowledge, technology transfer \& agent of economic development di tahun 2015-2019. Dosen di suatu institusi berperan penting sebagai salah satu agen yang dapat memacu keekonomian bangsa melalui output aktivitas yang mampu diterapkan di segala bidang. Hal ini meliputi peningkatan publikasi, relasi dengan industri, paten, sitasi, rangking universitas dan mengarah pada inovasi yang mendorong pengembangan ekonomi dan bermanfaat langsung bagi masyarakat (Renstra Kemenristek Dikti, 2015).

Dengan perubahan tersebut maka tuntutan pekerjaan pun semakin meningkat, muncullah harapan dan kesepakatan yang baru antara tenaga pendidik (dosen) dengan institusi baik secara tertulis maupun tidak tertulis. Perguruan tinggi selaku organisasi merupakan media pemberi kerja, sementara dosen adalah tenaga kerja. Institusi mengharapkan dosen melakukan tugas sesuai tuntutan yang baru dan dosen pun 
mengharapkan imbal balik yang sesuai atas tugas-tugasnya tersebut. Tenaga pendidik tentunya membawa kepentingan dan pengharapan yang berbeda-beda terhadap institusi pendidikan tempat ia bekerja.

Kontrak psikologis akan muncul ketika tenaga pendidik meyakini bahwa kewajiban institusi pendidikan pada tenaga pendidik akan sebanding dengan kewajiban yang akan diberikan tenaga pendidik pada institusi pendidikan. Hanya saja, meskipun kontrak psikologis ini telah dipenuhi oleh institusi pendidikan, namun semua hal itu tergantung pada persepsi yang diterima atau dirasakan oleh tenaga pendidik. Tenaga pendidik akan memiliki persepsi dan keyakinan masing-masing terhadap interaksi timbal balik yang diberikan institusi pendidikan kepadanya. Hal ini disebabkan oleh adanya karakteristik, nilai maupun sifat tenaga pendidik yang berbeda-beda antara satu dengan lainnya.

Mengingat bahwa pentingnya kontrak psikologis terhadap kesejahteraan psikologis, serta adanya kemungkinan terjadi perbedaan persepsi mengenai hubungan timbal balik tenaga pendidik dengan institusi pendidikan, maka salah satu upaya yang dapat dilakukan adalah dengan mengkaji signifikansi kontrak psikologis tenaga pendidik terhadap terbentuknya kesejahteraan psikologis. Selain itu, dikaji pula mengenai apa saja hal-hal yang dapat mempengaruhi terbentuknya kesejahteraan psikologis tenaga pendidik, seperti data demografi. Dalam penelitian ini, data demografi seperti jenis kelamin, usia, status dosen, lama kerja dan kepangkatan akan dikaji pula. Untuk itu, model teoritis yang diusulkan pada penelitian ini adalah pengaruh kontrak psikologis terhadap kesejahteraan psikologis, serta membahas mengenai faktor-faktor demografi lainnya yang mungkin memberikan pengaruh pada terbentuknya kesejahteraan psikologis.

Penelitian ini dapat memberikan tambahan informasi dalam rangka memahami pengaruh kontrak psikologis terhadap terbentuknya kesejahteraan psikologis. Untuk dosen selaku individu, penelitian ini dapat memberikan informasi mengenai pentingnya memiliki persepsi yang lebih positif pada upaya pemenuhan kontrak psikologis yang dilakukan pihak institusi. Dengan persepsi yang lebih positif, maka akan terbentuk perasaan aman secara psikologis pada diri individu dan menjadi salah satu indikator dari kesejahteraan psikologis. Mengingat bahwa persepsi terhadap kontrak psikologis terbentuk dari sisi individu atau dosen, maka implikasi praktis dari penelitian ini adalah Perguruan Tinggi selaku organisasi perlu mengetahui dan memastikan bahwa upaya pemenuhan yang dilakukan telah dipersepsi sesuai dengan harapan dosen sebagai sumber daya manusia yang utama. Beberapa penelitian sebelumnya, lebih fokus pada pelanggaran yang dilakukan perusahaan terhadap kontrak psikologis yang ada, yaitu Cassar, Vincent \&Buttigieg, Sandra C. (2015) maupun Kiazad, K., Seibert, S. E. and Kraimer, M. L. (2014). Penelitian lainnya membahas mengenai kaitan kontrak psikologis dengan kepuasan kerja, yaitu penelitian yang dilakukan oleh Bruce A. Rayton \& Zeynep Y. Yalabik (2014), yang mencoba menghubungkan antara pelanggaran kontrak psikologis terhadap keterlibatan kerja, dengan mengintegrasikan kepuasan kerja ke dalam hubungan pertukaran ini. Sejauh ini, masi sedikit penelitian yang membahas mengenai pengaruh kontrak psikologis terhadap terbentuknya kesejahteraan psikologis pada dosen di perguruan tinggi. Hal ini penting untuk melihat bahwa profesi tugas seseorang haruslah juga dilihat dari posisinya sebagai manusia, yang memiliki kebutuhan dan harapan demi pencapaian produktivitas perguruan tinggi yang lebih optimal. Dengan kebahagiaan dan kesejahteraan psikologis yang optimal maka seseorang akan berkesempatan lebih besar untuk meningkatkan unjuk kerja 
terutama di era saat ini dimana peran dosen sangat krusial mendorong percepatan perguruan tinggi menjadi agent of economic development pada beberapa tahun mendatang.

\section{Metode Penelitian}

Penelitian ini menggunakan pendekatan penelitian non-experimental dengan meninjau hubungan antaravariabel psychological contractterhadap psychological well being. Sebagaimana dalam tabel 1, sebaran demografi responden dalam penelitian ini sebanyak 202 orang dosen di Universitas X di Jawa Barat. Responden dipilih melalui random sampling sehingga setiap anggota populasi di Universitas $\mathrm{X}$ memiliki peluang yang sama untuk menjadi responden sesuai dengan kesediaannya. Seluruh populasi didata untuk membuat kerangka sampling dan menentukan secara acak nomor sample yang akan dijadikan responden. Setelah diperoleh, lalu kuesioner dikirimkan secara online kepada seluruh responden sehingga diperolehlah respond rate sebesar $27,6 \%$ dari total seluruh responden atau sekitar 202 orang.

Responden terdiri atas 55,45\% perempuan dan 44,55\% laki-laki. Berdasarkan usia didominasi oleh dosen di usia 31-40 tahun (38,61\%) dan usia 41-50 tahun $(29,70 \%)$. Status responden sekitar $79,21 \%$ adalah Pegawai Negeri Sipil (PNS) sedangkan sisanya berturut-turut Dosen Tetap Non PNS (DTNP), dosen luar biasa dan CPNS (Calon-PNS). Dari aspek lama kerja, responden paling banyak sudah bergabung menjadi dosen di Universitas $\mathrm{X}$ selama lebih dari 15 tahun $(38,12 \%)$ dan $1-5$ tahun sebesar $24,75 \%$. Sedangkan berdasarkan kepangkatan fungsional didominasi oleh Lektor dan Asisten Ahli (40,59\% dan 39,11\%).

Tabel 1.

Data Demografi Responden

\begin{tabular}{lll}
\hline & Aspek Demografi & Persentase \\
\hline Jenis Kelamin & Laki-laki & $44,55 \%$ \\
Usia & Perempuan & $55,45 \%$ \\
& $<31$ tahun & $12,87 \%$ \\
& $31-40$ tahun & $38,61 \%$ \\
& $41-50$ tahun & $29,70 \%$ \\
Status & 50 tahun & $18,81 \%$ \\
& CPNS & $5,45 \%$ \\
& PNS & $79,21 \%$ \\
& DTNP & $13,86 \%$ \\
& Luar Biasa & $1,49 \%$ \\
& $1-5$ tahun & $24,75 \%$ \\
& 6-10 tahun & $21,78 \%$ \\
& 11-15 tahun & $15,35 \%$ \\
& $>15$ tahun & $38,12 \%$ \\
Kepangkatan & Aissten Ahli & $39,11 \%$ \\
& Lektor & $40,59 \%$ \\
& Lektor Kepala & $18,81 \%$ \\
\hline
\end{tabular}


Melalui alat ukur psychological contract yang telah tervalidasi dengan analisis statistik, diperolehlah 14 item yang valid dengan koefisien reliabilitas 0,967 sehingga dapat dikatakan alat ukur ini memiliki reliabilitas yang sangat baik. Pada alat ukur psychological contractini digunakan lima skala pilihan (1-5) yang mengacu pada Rousseau (2000). Pengukuran psychological contract dengan mengukur kesenjangan (discrepancy measure), yaitu dengan memisahkan apakah item-item yang ditanyakan dipersepsi sebagai kewajiban organisasi pemberi kerja oleh pegawai serta pengukuran tentang sejauh mana organisasi pemberi kerja memenuhi kewajiban tersebut (antara lain Robinson, 1996; Coyle-Shapiro, 2000). Persepsi terhadap kewajiban dan pemenuhan kewajiban ditinjau dari 2 dimensi yaitu transactional contract dan relational contract.

Pengukuran psychological contractmelalui pendekatan ini dihitung dengan mengurangi skor pada tingkat kewajiban dengan skor sejauh mana kewajiban itu dipenuhi oleh organisasi pemberi kerja. Misalnya pada item dimana item tersebut dipersepsi sebagai hal yang sangat menjadi kewajiban organisasi pemberi kerja (skor 5) sedangkan respon pada persepsi terhadap pemenuhan pada skor 1(tidak dipenuhi oleh organisasi pemberi kerja) maka nilai psychological contract untuk item tersebut adalah 4 yang disebut sebagai psychological contract breach. Semakin negatif nilainya, maka mengindikasikan semakin besar pula pengingkaran atau psychological contract breachnya. Sebaliknya, jikaperbandingan antara respon persepsi terhadap kewajiban yang diemban oleh institusi dengan persepsi pemenuhan kewajiban adalah positif maka digolongkan sebagai psychological contract fulfillment. Tidak ada selisih (skor 0) menunjukkan terjadinya perfect contract fulfillment dimana apa yang dipersepsi sebagai kewajiban juga dipenuhi oleh institusi.Semakin positif perbedaannya berarti item tersebut dipersepsi bukanlah merupakankeharusan untuk dipenuhi namun tetap diberikan oleh institusi (over fulfillment).

Untuk mengendalikan pengaruh lain dari faktor demografi terhadap variabel dependen, maka dipertimbangkan pula jenis kelamin, usia, status, lama kerja dan kepangkatan responden. Sebagai variabel nominal yaitu jenis kelamin (Laki-Laki $=1$, Perempuan $=2$ ), status (PNS $=1$, Dosen Tetap Non PNS $=2$, Dosen Luar Biasa $=3$, CPNS = 4). Sedangkan faktor usia (tahun), masa kerja (jumlah tahun kerja dari awal masuk hingga saat ini) dan kepangkatan (golongan fungsional) termasuk dalam continous variable.

Adapun alat ukur psychological well being diturunkan dari alat ukur asal dari Carol D. Ryff (1989). Variabel psychological well-being dijelaskan melalui 18 item dari 6 dimensi yaituself acceptance, positive relation with others, autonomy, environmental mastery, purpose in life dan personal growth. Pada alat ukur ini, digunakan pilihan respon dengan skala Likert 1-4 mulai dari Sangat Tidak Sesuai hingga Sangat Sesuai. Alat ukur telah diadaptasi dan diuji reliabilitasnya dengan koefisien reliabilitas sebesar 0.962 (sangat baik). Untuk mempermudah memperoleh gambaran bagaimana kondisi psychological contract dan juga psychological well being maka dikategorisasikan sebagaimana landasan teori akan kondisi netral (terpenuhi, yaitu selisih 0-1) dan pembagian kelas pada kategori yang dibagi menjadi 3 bagian, yaitu tinggi, sedang, dan rendah.

Batasan umum kategorisasi yang telah dihitung berdasarkan skor ideal alat ukur adalah sebagai berikut: 
Tabel 2.

Kategorisasi Rerata Psychological Contractdan Psychological Well Being

\begin{tabular}{ccccc}
\hline & Tinggi & Sedang & Rendah & Netral \\
\hline Psy. Contract Breach & $(-3,67)-(-5,00)$ & $(-2,34)-(-3,67)$ & $(-1,00)-(-2,33)$ & $0,00-(-1.00)$ \\
Psy. Contract Fullfilment & $3,67-5,00$ & $2,34-3,67$ & $1,00-2,33$ & $0,00-1,00$ \\
Psy. Well Being & $3.01-4.00$ & $2.01-3.00$ & $1,00-2.00$ & - \\
\hline
\end{tabular}

Kline (2010) menyarankan pendekatan model dua tahap untuk menguji kesesuaian model dengan SEM. Pertama, melalui factorial validity dengan confirmatory factor analysis (CFA) terhadap 2 pengukuran. Selanjutnya divalidasi dengan menghitung estimasi dari parameter pengukuran model (structural model) dengan menentukan apakah model tersebut menunjukkan kesesuaian terhadap data. Setelah itu, dilakukanlah analisa statistik menggunakan SPSS versi 23 (Statistical Package for Social Sciences) dan Lisrel. Hubungan antara variabel independen terhadap variabel dependen dihitung melalui Analisis Regresi dengan taraf kepercayaan 95\% ( $\mathrm{p}<0,05$ ). Besaran selisih pemenuhan psychological contract yang bersifat positif dinamakan dengan Psychological Contract Fulfilment, sedangkan pemenuhan Psychological Contract yang negatif dinamakan dengan Psychological Contract Breach. Selain pengaruh dari psychological contract, dilihat pula bagaimana pengaruh faktor demografi terhadap psychological well being melalui uji korelasi menggunakan Analisis Korelasi Bivariat dengan taraf kepercayaan 95\% $(\mathrm{p}<0,05)$.

\section{Hasil dan Pembahasan}

Uji kesesuaian model dilakukan melalui 2 tahap hingga model fit, yang pertama dilakukan dengan mengugurkan item yang memiliki loading factor $<0.50$ (Nunnally \& Bernstein, 1994) sehingga dikatakan bahwa seluruh itemnya dapat menggambarkan dengan baik konstruk dalam psychological contract baik transactional maupun relational constract.

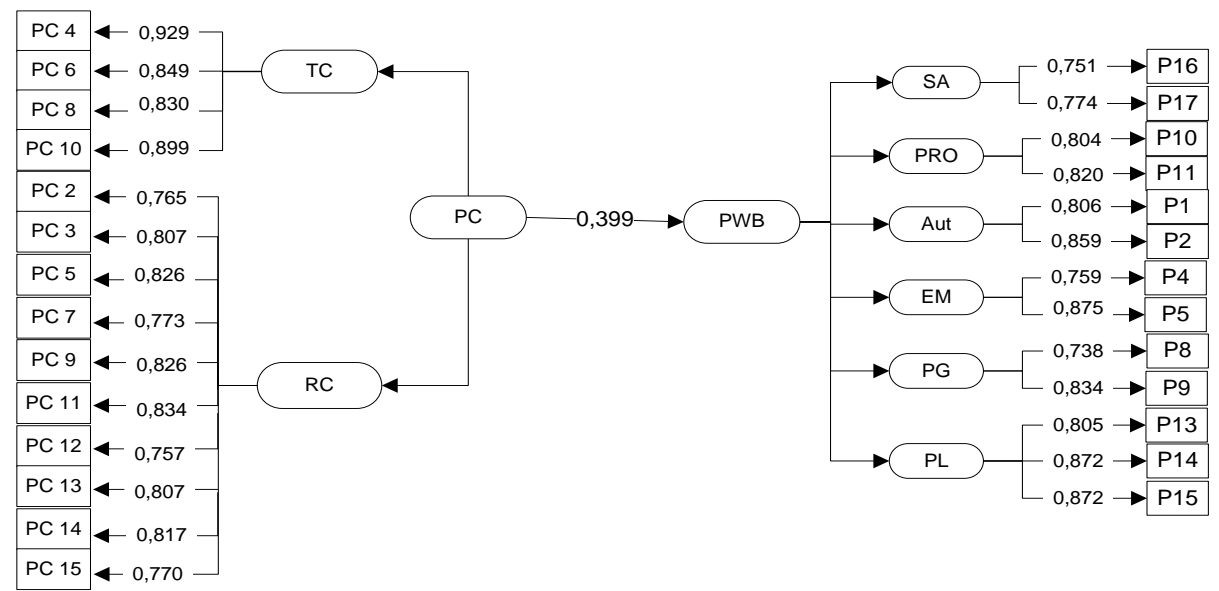

Gambar.1 Bagan Uji Kesesuaian Model

Melalui confirmatory factor analysis pada variabel psychological contract maka item 1 gugur. Oleh karena itu tersisa 4 item untuk dimensi transactional contract dan 10 untuk dimensi relational contract. Sedangkan pada variabel psychological wellbeing 
terdapat 5 item gugur yaitu 3, 6, 7, 12 dan 18 sehingga masing-masing dimensi diwakili oleh 2-3 item. Dimensi self acceptance (SA) sebanyak 2 item, dimensi positive relation to others (PRO) 2 item, autonomy 2 item, environment mastery item, purpose in life 2 item serta personal growth 2 item.

Setelah itu, diuji kembali menggunakan struktural model dengan beberapa parameter yaitu Standardized Root Mean Square Residual (SRMR) yang didukung dengan CFI (Comparative Fit Index), NNFI (Non normative Fit Index) dan RMSEA (Root Mean Square Error Approximation). Menurut Hu \& Bentler (1999), cut off value untuk SRMR adalah mendekati 0,08; CFI 0,95 ; NNFI mendekati 1,00 dan RMSEA mendekati 0,06. Berdasarkan Tabel 1, nampak bahwa Chi-Square sebesat 118, 98 dengan faktor lain untuk menilai kecocokan model psychological contract dan itemitemnya. Menurut Anderson \& Gerbing (1988; Bollen, 1989) secara statistik Chi-Square akan menghasilkan perbedaan yang signifikan ketika model digolongkan dalam good fit. Oleh karena itu, dilakukakanlah tes Comparative Fit Index (CFI) dengan hasil 0,99 yang mendekati 0,95 . Indikator yang lainnya pun menunjukkan hal yang relatif serupa dengan nilai yang mendekati cut off value baik itu RMSEA sebesar 0,069 lalu NNFI $(0,99)$, dan SRMR $(0,027)$ juga $p$ value $(0,000)$.

Tabel 3.

Ringkasan ParameterUji Kesesuaian Model

\begin{tabular}{ccccccc}
\hline $\mathrm{S}-\mathrm{B} \chi 2$ & $\mathrm{df}$ & $\mathrm{p}$ & $\mathrm{RMSEA}$ & $\mathrm{NNFI}$ & $\mathrm{CFI}$ & SRMR \\
\hline 118,98 & 61 & 0,000 & 0,069 & 0,99 & 0,99 & 0,027 \\
\hline
\end{tabular}

Setelah model dinyatakan fit, maka selanjutnya dilakukanlah perhitungan statistik lainnya yaitu statistika deskriptif, analisa pengaruh antara psychological contract terhadap psychological well being dan pengaruh demografi terhadap psychological well being melalui analisa regresi. Sebagaimana hasil statistika deskriptif pada tabel 4, nilai negatif pada psychological contract disebut sebagaipsychological contract breach. Hal ini berarti ada perbedaan atau gap antara persepsi kewajiban yang harus dipenuhi oleh institusi dan persepsi terhadap realisasi pemenuhannya. Secara kuantitatif, gap yang muncul sebesar -1,419 masih tergolong sebagai gap yang rendah (Tabel 1). Artinya, hanya sedikit saja pemenuhan kebutuhan yang dipersepsikan belum optimal oleh responden.Hal ini terjadi baik di transactional contract maupun relational contract.

Dengan tingkat psychological contract breach yang rendah, sebaliknyapsychological well being tergolong dalam rerata nilai yang relatif tinggi yaitu sekitar 3.129. Dimensi dengan rerata terbesar ada pada personal growth dan purpose in life. Hal ini berarti, responden mempersepsi pertumbuhan diri dan dimilikinya tujuan hidup sebagai aspek yang menunjang kesejahteraan psikologisnya. Adanya harapan, keinginan untuk selalu maju dan berkembang membuat kondisi psikologis mereka lebih positif. Sedangkan rerata terkecil ada pada dimensi autonomy dan positive relation meskipun masih tergolong dalam tingkat yang sedang. Dengan demikian, responden merasa bahwa ia masih terikat dengan aturan-aturan yang berlaku di institusi, tidak dapat lepas begitu saja dan menentukan sendiri keinginan dalam pekerjaan. Tidak selalu harapan dapat terpenuhi, begitu pula dengan keputusan dan pandangan terhadap sesuatu. Hal ini harus selalu disesuaikan dengan kepentingan dan aturan yang berlaku di organisasi meskipun kadangkala dirasakan kurang menyenangkan. Dari sisi positive relationyang berada dalam taraf sedang, maka dapat dikatakan bahwa relasi dengan 
rekan lain masih memadai, meskipun tidak begitu menekankan pada kedekatan dan kehangatan. Hal ini masih berperan dalam menjaga kebahagiaan diri.

Tabel 4

Statistika Deskriptif

\begin{tabular}{lccc}
\hline Variabel dan Dimensi & Mean & SD & Std. Error Mean \\
\hline Psychological contract breach & $-1,419$ & 0,954 & 0,067 \\
Transactional contract breach & $-1,277$ & 1,070 & 0,075 \\
Relational contract breach & $-1,476$ & 0,931 & 0,065 \\
Psychological well being & 3,129 & 0,390 & 0,027 \\
Self Acceptance & 3,114 & 0,581 & 0,040 \\
Positive Relation & 2,928 & 0,613 & 0,431 \\
Autonomy & 2,992 & 0,565 & 0,039 \\
Environmental Mastery & 3,052 & 0,524 & 0,037 \\
Purpose in Life & 3,196 & 0,583 & 0,041 \\
Personal Growth & 3,430 & 0,506 & 0,035 \\
\hline
\end{tabular}

Meskipun, secara kuantitatif gap negatif pemenuhan kebutuhan tergolong rendah, namun ternyata perbedaan tersebut bermakna bagi responden. Sebagaimana tabel 4, diperoleh bahwa nilai perbedaan rerata atara persepsi terhadap kebutuhan dan persepsi terhadap pemenuhan oleh institusi adalah signifikan. Tidak hanya di transactional contract, tetapi juga di dimensi relational contract. Artinya, meskipun hanya beberapa hal saja yang dirasa belum terpenuhi secara optimal oleh institusi, namun ternyata dirasakan penting bagi responden.

Tabel 5

Hasil Uji Beda

\begin{tabular}{|c|c|c|c|c|c|c|c|c|}
\hline & Paired Variables & Mean & SD & Lower & Upper & $\mathbf{T}$ & df & $\begin{array}{l}\text { Sig. (2- } \\
\text { tailed) }\end{array}$ \\
\hline Pair 1 & $\begin{array}{l}\text { Persepsi kewajiban-persepsi } \\
\text { pemenuhan transactional } \\
\text { contract }\end{array}$ & 5,11 & 3,25 & 4,66 & 5,56 & 22,36 & 201 &, 000 \\
\hline Pair 2 & $\begin{array}{l}\text { Persepsi kewajiban-persepsi } \\
\text { pemenuhan relational contract }\end{array}$ & 14,76 & 5,98 & 13,93 & 15,59 & 35,07 & 201 &, 000 \\
\hline
\end{tabular}

Mekanisme terjadinya psychological contract breach dimulai dari adanya hubungan antara individu sebagai karyawan dan institusi pemberi kerja atau organisasi yang menyebabkan masing-masing pihak mengembangan pandangan maupun harapan tertentu dan berkeinginan untuk diwujudkan oleh pihak yang lain. Dalam hal ini, sebagai responden yaitu dosen yang merupakan anggota organisasi, memiliki harapan implisit maupun eksplisit tentang apa yang mereka harapkan dari institusi selaku 
organisasi tempat bekerja. Selaku pekerja, dosen mencari martabat, penghargaan, kebijakan yang mempengaruhi karir mereka, rekan kerja yang kooperatif, dan kompensasi yang adil. Institusi selaku organisasi pun memiliki harapan terhadap karyawannya, untuk dapat menampilkan performa yang diharapkan. Harapan bagi salah satu pihak menjadi kewajiban bagi pihak lainnya. Harapan dan kewajiban secara timbal balik antara individu dan organisasi dimana ia berkerja inilah yang disebut sebagai Psychological Contract (Rousseau, 1990).

Psychological contract ini dapat dilihat dari dua sisi yaitu transactional dan relational contract(Rousseau, 1989). Transactional contract merupakan keyakinan individu terhadap kewajiban timbal balik antara karyawan dengan organisasi yang memberikan pekerjaan dengan pengelolaan jangka pendek, eksplisit, dan menekankan pada aspek ekonomi. Sedangkan relational contract adalah keyakinan individu terhadap kewajiban bersama antara karyawan dengan organisasi yang didasarkan pada unsurunsur sosio-emosional, bersifat jangka panjang, tidak spesifik, menekankan pada pertukaran personal dan berdasarkan pada pertukaran nilai.Perbandingan antara persepsi terhadap kewajiban/tugas yang harus dipenuhi oleh institusi dengan persepsi terhadap pemenuhan kewajiban tersebut baik di transactional maupun relational akan memunculkan psychological contract fulfillmentataupunpsychological contract breach.

Di transactional contract, nilai gap negatif antara rerata persepsi kewajiban dan persepsi pemenuhannyatergolong rendah, hanya sekitar-1,277 namun signfikan. Dengan begitu, dapat mengindikasikan bahwa secara bermakna responden merasa kewajibankewajiban transaksional seputar benefit, imbal balik dan kesesuaian antara tugas dengan job descriptionmasih belum dipenuhi secara optimal oleh institusi. Adapun di dimensi relational, psychological contract breachsebagai fungsi dari nilai rerata discrepancy antara persepsi terhadap kewajiban dan persepsi pemenuhan pun masih tergolong rendahdengan nilai -1,476.Meskipun kesenjangannya tergolong rendah namunsignifikan, hal ini berarti masih adanya kesenjanganmengenai persepsi mengenai apa yang diterima dengan apa yang dijanjikan oleh institusi (Conway \& Briner, 2005).

Jika dihubungkan dengan analisa loading factor, maka item yang memberikan sumbangan terbesar atas terjadinya psychological contract breach yaitu pada item 4 dan item 10 di dimensi transactional contract dengan nilai loading 0,929 serta 0,899. Pernyataan pada item 4 adalah "memberikan insentif sesuai dengan beban kerja sebagai dosen",sedangkan item 10 yaitu "memberikan tugas sesuai dengan kontrak kinerja". Hal ini berarti, kondisi yang dirasakan lebih banyak berperan terhadap psychological contract breach pada dimensi transaksional adalah pemberian insentif yang belum sesuai dengan beratnya beban kerja serta tugas-tugas tambahan yang lebih banyak sehingga dipersepsikan lebih membebani.

Pada dimensi relational contract, item-tem yang memberikan peran besar terhadap terjadinya gap dalam pemenuhan kewajiban institusi adalahterutama item 11, 5 dan 9. Item 11 yaitu "memberikan reward dan punishment secara adil dan merata" dengan loading factor 0,834; item 5 loading factor 0,826 "memperhatikan kesehatan dan keamanan dalam bekerja" dan item 9 sebesar 0,826 yaitu "memperhitungkan benefit yang sama bagi semua dosen sesuai dengan jabatan baik secara fungsional maupun struktural".

Berdasarkan Bagan 1, nilailoading factor diatas 0,8 lebih banyak berada di dimensi transactional contract, jika dikaitkan dengan adanya perbedaan negatif signifikan antara persepsi terhadap kewajiban institusi terhadap tingkat pemenuhan kewajiban maka lebih banyak dibentuk oleh harapan para tenaga pendidik yang sifatnya 
pertukaran ekonomi. Diantaranya yang menonjol adalah harapan akan adanya insentif kerja yang sesuai dengan berat dan besarnya tanggung jawab pekerjaan yang diemban oleh tenaga pendidik serta relevansi pemberian kerja sesuai dengan kesepakatan yang telah dibuat setiap awal semester. Benefit dan sistem imbal balik yang memadai, balanceddan memenuhi harapan para tenaga pendidik akan menentukan bagaimana ia dapat merasakan exchange relationship yang mutual, sebanding dengan kontribusi yang telah ia berikan kepada institusi. Transactional contract menekankan pada hubungan timbal balik yang bersifat moneter dengan keterlibatan individu yang terbatas dalam organisasi maupun hubungannya dengan individu lain di organisasi (Conway \& Shapiro, 2011). Dengan begitu, akan terlihat bahwa melalui ketatnya kontrak kinerja yang dibuat antara tenaga pendidik dengan instusi, maka pertukaran relasi kerja menjadi lebih sempit (narrow), tenaga pendidik akan merasa cukup terpenuhi hanya ketika benefit yang ia terima dirasa relevan dengan kelelahan yang ia berikan bagi institusi.

Salah satu konsekuensi dari psychological contract adalah psychological well being (Cassar \& Buttigieg, 2015; Vart, Linde \& Cockeran, 2013; Cuyper \& Witte, 2006). Psychological well being menggambarkan kondisi positif seseorang terhadap dirinya. Berdasarkan penilaian terjadinya breach atas pemenuhan kewajiban dari institusi maka diprediksikan hal tersebut akan berdampak pada bagaimana perasaanperasaan seseorang di seputar aktivitas dan kehidupan. Pada responden dalam penelitian ini, kondisi well being lebih banyak dibentuk oleh item-item di nomor 2, 5, 14 dan 15 (Bagan 1). Dengan rerata total keseluruhan well being adalah 3,129 dari skala 1-4, tergolong tinggi. Menurut responden maka kondisi tersebut lebih banyak disumbang oleh perasaan mereka mengenai kebahagiaan diri yang dianggap jauh lebih penting daripada pengakuan dari institusi semata, persepsi mengenai aktivitas sehari-hari yang begitu menyita kesibukan namun memberi makna pada diri mereka. Meskipun dengan tuntutan yang tinggi sebagai dosen, perasaan positif diri yang dirasakan salah satunya berasal dari peran sebagai pendidik, banyak berbagi, sharing ilmu dan memberikan wawasan pada mahasiswa. Bagi mereka, tujuan untuk bermanfaat bagi orang lain nampaknya memberikan pengaruh yang positif terhadap kepuasan dalam hidup mereka.

Atas hasil uji pengaruh psychological contract terhadap psychological well being, maka dengan perbandingan T-hitung yang lebih kecil dari T-Tabel maka disimpulkan bahwa hipotesis ditolak. Hal ini berarti, terdapat pengaruh yang signifikan psychological contract terhadap psychological well being. Artinya, semakin rendah gap dan semakin positif perbedaan antara antara persepsi kewajiban dan persepsi pemenuhannya maka individu akan merasa terpenuhi harapan-harapan maupun kebutuhannya di institusi (fulfilled). Dengan perasaan "terpenuhi", maka akan berdampak pada semakin meningkatnya perasaan positif pada individu (Cuyper \& Witte, 2006). Perasaan inilah yang mengantarkan pada tingkat kesejahteraan psikologis yang lebih baik. Sebaliknya, jika gap antara persepsi kewajiban dan persepsi pemenuhan oleh institusi semakin besar dan negatif, maka hal ini berarti terjadi psychological contract breach. Kondisi breach ini yang akan mempengaruhi kondisi psychological well being menjadi lebih rendah. Dosen akan merasa institusi tidak memenuhi harapan-harapannya dalam hubungan kerja sehingga mengganggu kebahagiaan psikologisnya.

Ketika institusi dan dosen sebagai pegawai memahami kewajiban mutual yang harus dipenuhi, serta memberikan kontribusi yang seimbang, akan menghasilkan hubungan kerja yang dapatmendatangkan dampak positif bagi keduanya (Dabos \& Rousseau, 1994; Shore \& Barksdale, 1998). Psychological contractdengan kondisi yang 
seimbang antara persepsi mengenai kewajiban dengan pemenuhannya akan berdampak pula terhadap perasaan well being yang lebih tinggi dibandingkan dengan ketika terjadi psychological contract breach antara individu dengan institusi yang mempekerjakannya (Ruokolainen, et al., 2016). Pernyataan tersebut sejalan pula dengan hasil penelitian ini, rendahnya tingkat persepsi mengenai gap pemenuhan kebutuhan oleh institusi untuk dosen berdampak pada tingkat perasaan positif yang lebih baik.

Tabel 6 .

Hasil Uji Regresi

\begin{tabular}{ccccccc}
\hline & $\begin{array}{c}\text { Original } \\
\text { Sample } \\
\text { Estimate }\end{array}$ & $\begin{array}{c}\text { Mean of } \\
\text { Subsamples }\end{array}$ & $\begin{array}{c}\text { Standard } \\
\text { Deviation }\end{array}$ & T-Statistic & T Tabel & Keterangan \\
\hline $\begin{array}{c}\text { Psy Contract }- \\
\text { Psy Well Being }\end{array}$ & 0,399 & 0,407 & 0,178 & 2,241 & 1,972 & signifikan \\
\hline
\end{tabular}

Namun demikian, persepsi mengenai pemenuhan kewajiban oleh institusi masih dalam taraf minus, belum sampai pada tingkat perfect fullfilment (gap $=0$ ), oleh sebab itu masih ada pemenuhan kewajiban yang dianggap kurang. Diantaranya yang menonjol berdasarkan nilai loading factor adalah berkaitan dengan pemenuhan kewajiban transaksional. Dalam hal ini, masih belum memadainya pemberian insentif, tangible reward yang bersifat ekonomi dibandingkan dengan beban kerja yang diemban. Pemberian benefityang setara bagi seluruh dosen juga dianggap masih belum optimal sehingga menimbulkan gap dalam hubungan timbal balik diantara kedua belah pihak.

Temuan diatas dapat pula dijelaskan berdasarkan faktor kondisi yang sedang terjadi di organisasi. Dalam hal ini, kondisi institusi yang sedang dalam masa perubahan yang cukup besar nampaknya menjadi isu utama yang mewarnai terjadinya diskrepansi antara kesepakatan dan harapan pada tenaga pendidik dengan instusi. Selaras dengan hal ini, Rousseau (1998) menjelaskan bahwa pada organisasi yang sedang mengalami perubahan dan guncangan maka faktor perubahan serta sikap dalam menghadapi perubahanlah yang akan lebih berinteraksi dengan psychological contract.Perhatian lebih banyak terfokus pada imbal balik pekerjaan yang lebih bersifat tangible dan transaksional. Dengan begitu, hal tadi dapat bepengaruh pada tingkat psychological contract breach terutama terkait dengan obligasi transaksional, perjanjian implisit yang melibatkan hal-hal bersifat ekonomi.

Relatif rendahnya tingkat breach, membuat psychological well being masih berada dalam taraf yang baik meski belum merata di seluruh dimensinya. Hal ni terutama disebabkan oleh adanya penguatan atas kebermaknaan kerja yang diyakini dan dirasakan oleh tenaga pendidik bahwa aktivitas yang dilakukan bermanfaat dan membawa kebaikan bagi orang lain seperti mahasiswa ataupun masyarakat. Mereka merasa bahagia saat berbagi ilmu kepada mahasiswa, merasa puas ketika turut sharing pengalaman, pengetahuan dan bertukar pikiran dengan generasi-generasi cerdas di masa ini. Pada studi ini ditemukan pula bahwa nilai luhur tujuan hidup seperti meniatkan bekerja untuk ibadah, mengabdi untuk mencerdaskan mahasiswa sehingga dapat berkontribusi terhadap negeri meski hanya melalui profesi yang dijalani. Bagi mereka, hal ini menjadi hal yang juga mendorong kebahagiaan mereka secara psikologis dalam menjalani pekerjaan sebagai dosen.

Selain itu, dihitung pula faktor demografi yang berperan terhadap pembentukan psychological well being. Berdasarkan hasil perhitungan regresi, diperoleh bahwa ternyata faktor jenis kelamin saja yang berkaitan dengan perasaan positif pada 
seseorang. Hal ini didukung oleh beberapa temuan penelitian sebelumnya yang menyatakan adanya kaitan antara peran sehari-hari dengan tingkat psychological wellbeing seseorang. Secara umum, jika dilihat dari dimensi psychological well-being, pria memiliki tingkat psychological well-being yang lebih baik dibandingkan dengan wanita. Sebaliknya, menurut Escriba-Aguir (2004) wanita yang menjalani peran sebagai pekerja akan memiliki psychological well-being lebih tinggi. Hal ini terkait dengan kepuasaan yang mereka rasakan antara keberhasilan dalam keluarga dan pekerjaan.

Tabel 7.

Hasil Uji Regresi Demografi

\begin{tabular}{|c|c|c|c|c|c|c|c|c|c|c|}
\hline & Variables & Mean & SD & 1 & 2 & 3 & 4 & 5 & 6 & 7 \\
\hline 1 & Jenis Kelamin & 1,55 & 0,49 & 1 & & & & & & \\
\hline 2 & Usia & 2,54 & 0,94 & 0,053 & 1 & & & & & \\
\hline 3 & Status Dosen & 2,11 & 0,49 & 0,005 &,$- 146^{*}$ & 1 & & & & \\
\hline 4 & Lama Kerja & 2,67 & 1,22 & 0,124 &, $808^{* *}$ &,$- 161^{*}$ & 1 & & & \\
\hline 5 & Kepangkatan & 1,83 & 0,78 & 0,095 &, $683^{* *}$ &,$- 143^{*}$ &, $759^{* *}$ & 1 & & \\
\hline 6 & Psy. Well Being & 1,37 & 0,51 &,$- 164 *$ & 0,029 & 0,02 & $-0,55$ & $-0,38$ & 1 & \\
\hline
\end{tabular}

Menurut Elst, et al., (2014) menyatakan bahwa pengingkaran kesepakatan psikologis akan berdampak pada job insecurity yang mengganggu kenyamanan kerja. Sebaliknya, dalam banyak studi ditemukan bahwa dengan kondisi psikologis yang penuh kepuasan, positif dan bahagiaakan mungkin untuk dicapai melalui kesimbangan timbal balik pemenuhan kewajiban masing-masing pihak (Zhao, et al., 2007).Tidaklah mudah bagi suatu institusi dan pekerjanya untuk dapat mencapai diskrepansi netral (atau nol) antara persepsi pekerja atas kewajiban institusi dengan persepsi pekerja atas pemenuhan kewajiban tersebut bagi mereka. Artinya, perlu upaya yang berkesinambungan untuk dapat menyeimbangkan interaksi hubungan timbal balik yang dipersepsikan seimbang antara institusi dengan pekerjanya baik dalam harapan yang sifatnya transaksional maupun relasional.

Melalui studi ini ditemukan bahwa ternyata meskipun terjadi psychological contract breach, dalamtaraf yang rendah, maka tidak lantas membuat tingkat kesejahteraan psikologis dosen menurun begitu saja. Aspek yang banyak berperan sehingga mereka merasakan breach lebih didominasi oleh faktor finansial seperti insentif, reward dan economic benefit. Namun demikian, mereka masih tetap merasakan kondisi psikis yang positif karena keyakinan mereka bahwa profesi sebagai dosen memberikan makna tersendiri terhadap pengembangan pribadi. Melalui interaksi dengan mahasiswa dan tugas-tugas tridharma perguruan tinggi menjadi pengalaman yang menambah pengetahuan, keterampilan dan kesempatan untuk selalu bertumbuh dengan keilmuan yang ditekuni.

Temuan ini memberikan khasanah baru bagi keilmuwan, bahwa profesi sebagai dosen tidak semata-mata mengenai transaksi ekonomis saja, namun lebih dari itu menemukan makna hidup dengan banyak berbagi ilmu, profesi ini sebagai bagian dari tujuan hidupnya untuk terus menemukan arti dan kesempatan dalam memberikan kebaikan pada orang lain khususnya mahasiswa didik.Nampaknya, makna bekerja bagi profesi dosen cukup memberi warna positif dalam menjaga komitmen terhadap profesi mereka.

Psychological contract, sangat erat kaitannya dengan praktik-praktik pengelolaan sumber daya manusia (Festing \& Schafer, 2014) di institusi pendidikan. 
Pada akhirnya hal ini sangat penting untuk dilakukan secara sungguh-sungguh sehingga sebagai angota organisasi baik manajemen maupun pekerja dapat saling terbuka menyuarakan harapan-harapannya. Bagi manajemen perlu untuk menyampaikan ide-ide dan pertimbangan strategis dalam setiap keputusan pengelolaan yang bersifat transaksional maupun relasional sehingga pekerja menjadi lebih paham akan harapan timbal balik antara kedua belah pihak. Hal ini dilakukan demi menjaga kondisi pekerja yang tetap well being secara psikologis sehingga performa dalam menjalankan tugas pengajaran, penelitian dan pengabdian masyarakat akan tetap dapat terjaga.

\section{Simpulan}

Berdasarkan hasil paparan penelitian diatas, dapat disimpulkan bahwa psychological contract memiliki pengaruh signifikan terhadap psychological well being. Ditemukan pula, bahwa adanya kesenjangan dalam psychological contract lebih banyak dibentuk oleh aspek-aspek yang sifatnya transactional seperti benefit, imbal balik, penugasan sesuai dengan beban kontrak kinerja antara tenaga pendidik dengan institusi. Hal ini berkaitan pula dengan kondisi perubahan yang sedang terjadi di lingkungan institusi. Dalam taraf breach yang rendah, kondisi psychological well being masih bertahan taraf yang cukup baik. Hal ini merupakan keunikan dalam profesi dosen, psychological well being pada tenaga pendidik lebih dibentuk oleh adanya keyakinan bahwa profesi dan aktivitasnya bermakna bagi orang banyak, tidak pernah sekedar siasia, memiliki tujuan luhur dalam mendukung pengembangan generasi negeri. Sebagai pengembangan dari studi ini, maka untuk mengkaji lebih dalam faktor yang berpengaruh terhadap psychological well being serta melengkapi uji kesesuaian model maka dapat pula dihubungkan dengan variabel lain sebagai variabel perantara ataupun konsekuensi dari psychological well being pada tenaga pendidik di perguruan tinggi. Dengan begitu, diharapkan akan diperoleh model yang komprehensif sebagai pijakan awal untuk meningkatkan optimalitas unjuk kerja dosen sebagai sumber penggerak utama di perguruan tinggi yang dapat menopang pengembangan ekonomi masyarakat.

\section{Daftar Pusataka}

Aggarwal, U. \& Bhargava, S. (2010). The Effects Of Equity Sensitivity, Job Stressors And Perceived Organizational Support On Psychological Contract Breach. The Journal of Business Perspective, Vol.14, No.1.

Aggarwal, U. \& D'Souza K. C. (2012). Transformational Leadership : The Link between P-O Fit, Psychological Contract \& Signature Experiences. The Indian Journal of Industrial Relation, Vol.47, No.3.

Armstrong, Michael. (2007). A Handbook of Employee Reward Management : A Guide to Action. London : Kogan Page Ltd.

Argyris, C. (1960). Understanding Organizational Behavior. Homewood : IL : Dorsey Press. 
Anderson, J. C., \& Gerbing, D. W. (1988). Structural equation modeling in practice:A review and recommended twostep approach. Psychological Bulletin, 103, 411423.

Bal,P. Matthijs, et al. (2008). Psychological contract breach and job attitudes: A metaanalysis of age as a moderator. Journal of Vocational Behavior 72 (2008) 143158

Bal, P. Matthijs., De Cooman, Rein\& Mol, Stefan T. (2013). Dynamics of Psychological Contracts with Work Engagement and Turnover Intention: The Influence of Organizational Tenure.European Journal of Work and Organizational Psychology, 2013, 22, 107-122.

Blau, P. (1964). Exhange and Power in Social Life : New York : Wiley.

Bollen, K. A. (1989). Structural equations with latent variables. New York, NY: Wiley.

Bradburn, M. 1969. The Structure of Psychological Well-Being. Chicago: Aldine Publishing Company.

Cassar, Vincent\& Buttigieg, Sandra C.(2015). Psychological contract breach, organizational justice and emotional well-being. Personnel Review, Vol. 44 Iss: 2, pp. $217-235$

Conway, Neil \& Brinner, Rob B. (2002). Full-Time versus Part-Time Employees: Understanding the Links between Work Status, the Psychological Contract, and Attitudes. Journal of Vocational Behavior 61, 279-301

Conway, Neil \& Brinner, R.B. 2005. Understanding Psychological Contracts at Work : A Critical Evaluation of Theory and Research. Oxford University Press.

Conway, Neil and Coyle-Shapiro, Jacquelline A-M. (2011). The Reciprocal Relationship Between Psychological Contract Fulfilment and Employee Performance and The Moderating Role of Perceived Organizational Support And Tenure.Journal of Occupational and Organizational Psychology, 85: 277299.

Coyle-Shapiro, Jacquelline A-M \& Kessler, I. (2000). Consequences of the Psychological Contract for the Employment Relationship : A Large Scale Survey. Journal of Management Studies, 37, 903-930.

Coyle-Shapiro, Jacquelline A-M. (2002). Exploring Reciprocity Through the Lens of the Psychological Contract : Employee and Employer Perspectives. European Journal of Work and Organizational Psychology. Volume 11 (1), 1-18/

Coyle-Shapiro, Jacquelline A-M\& Conway, Neil. (2005). Exchange Relationship : Examining Psychological Contract and Perceived Organizational Support . Journal of Applied Psychology. 90, 774-781.

Coyle-Shapiro, Jacquelline A-M and Parzefall. (2008). Psychological Contracts. In : Cooper, Cary $L$ and Barling, Julian (eds). The SAGE Handbook of organizational behavior. SAGE Publication : London, UK

Cuyper, N.D \& De Witte, Hans. (2006). The impact of job insecurity and contract type on attitudes, well-being and behavioural reports: A psychological contract 
perspective. Journal of Occupational and Organizational Psychology, 79, 395409

Dabos, G.E \& Rousseau, D.M. (2004). Mutual \& Reciprocity in the Psychological Contracts of Employee and Employers. Journal of Applied Psychology, 89, 5272

De Vos, A., Buyens, D., \& Schalk, R. (2003). Psychological contract development during organizationalsocialization: Adaptation to reality and the role of reciprocity. Journal of Organizational Behavior, 24,537-559.

Eisenberger, R., Huntington, R., Hutchison, S., \& Sowa, D. (1986). Perceived organizational support. Journal of Applied Psychology, 71, 500-507.

Elst, Tinne Vander, et al., (2014). Explanations of the Relationships Between Job Insecurity, Job Strain and Coping Reactions: Towards a Theoretical Integration. Journal of Stress \& Health, Wiley Online Library, 10.1002/smi.2584

Escriba-Aguir, V \& Tenias-Burillo, J.M. (2004). Psychological Well-Being Among Hospital Personnel: The Role of Family Demands and Psychosocial Work Environment. International Archieves of Occuational \& Environmental Health, 77, 401-408

Fariza Luthfia danaz Nasution \& Ali Nina Liche Seniati. Pengaruh Kontrak Psikologis Terhadap Komitmen Organisasi Pada Tenaga Kerja Outsourcing di Perusahaan Penyedia Jasa Outsourcing,. Fakultas Psikologi Universitas Indonesia. 2013.

Festing, Marion \& Schafer, Lynn. (2014). Generational Challenges to Talent Management: A Framework for Talent Retention Based on the PsychologicalContract Perspective. Journal of World Business, 49, 262-271

Guest, D. (1998). 'Is The Psychological Contract Taking Seriously?'. Journal of Organizational Behavior, 19, 649-664.

Griffin, R. W \& Moorhead, G. (2010). Organizational Behavior : Managing People and Organizations. Ninth Edition. South-Western College Publising.

Hu, L., \& Bentler, P. M. (1999). Cutoff criteria for fit indexes in covariance structure analysis: Conventional criteria versus new alternatives. Structural EquationModeling, 6, 1-55.

Kiazad, K., Seibert, S. E. and Kraimer, M. L. (2014), Psychological contract breach and employee innovation: A conservation of resources perspective. J Occup Organ Psychol, 87: 535-556.

Kline, R. B. (2010). Principles and practice of structural equation modeling (3rd ed.). New York, NY: Guilford Press.

Lee Hung-Wen, Liu Ching-Hsiang. (2009). The Relationship Among Achievement Motivation, Psychological Contract and Work Attitude. Journal of Social Behavior and Personality. 37 (3).

McDonald, D.J \& Makin, P.J. (2000) The Psychological Contract, Organizational Commitment and Job Satisfaction of Temporary Staff. Leadership \& Organization Development Journal, 21, 84-91. 
Morrison, Elizabeth Wolfe \& Robinson, Sandra L. (1997). When Employee Feel Betrayed : A Model How Psychological Contract Violation Develops. The Academy of Management Review. Volume 22 No 1, 226-256.

Ng, Thomas W.H \& Feldman, Daniel C. (2009). Age, work experience, and the psychological contract. Journal of Organizational Behavior, 30, 1053-1075.

Nunnally, J. C., \& Bernstein, I. H. (1994). Psychometric theory (3rd ed.). New York, NY:McGraw-Hill.

Nelson, L., Tonks, G. \& Weymouth, J. (2006). The Psychological Contract and Job Satisfaction: Experiences of a Group of Casual Workers, Research and Practice in Human Resource Management, 14(2), 18-33.

Noer Aisyah Barlian. Pengaruh Tipe Kepribadian, Kontrak Psikologis, Komitmen Organisasi, Motivasi dan Kepuasan Kerja Terhadap Organizational Citizenship Behavior (OCB) dan Kinerja Karyawan Di Rumah Sakit Paru Kabupaten Jember. Program Studi Manajemen, Fakultas Ekonomi, Universitas Jember.

Perananta Sembiring \& Eka Danta Jaya Ginting. Kontrak Psikologis dan Masa Kerja Sebagai Prediktor Trust Karyawan Terhadap Organisasi. Fakultas Psikologi Universitas Sumatera Utara.

Pedoman Beban Kerja dan Evaluasi Pelaksanaan Tridharma Perguruan Tinggi, Direktorat Jendral Pendidikan Tinggi-Departemen Pendidikan Nasional, 2010:5

Rayton, Bruce A. \& Yalabik, Zeynep Y. (2014)“Work engagement, psychological contract breach and job satisfaction" Pages 2382-2400Published online: 14 Jan 2014

Robinson, S.L., Rousseau, D.M and Kraatz, Mattew S. (1994). Changing Obligation and The Psychological Contract : A Longitudinal Study. Academy of Management Journal. Volume 37 No 1, 137-152.

Robinson, S.L and Morrison, E.W. (1995). Psychological Contract and OCB : The Effect of Unfulfilled Obligation and Civic Virtue. Journal of Organizational Behavior, 16, 289-198.

Robinson, S. L. (1996). Trust and Breach of the Psychological Contract. Administrative Science Quarterly, 574-599.

Rousseau, D.M. (1989). Psychological and implied contracts in organizations. Employee Responsibilities and Rights Journal 2, no. 2: 121-38

Rousseau, D.M. (1990). New hire perceptions of their own and their employer's obligations. Journal of Organizational Behavior 11, no. 5: 389-400

Rousseau, D.M., and Parks, Judi Mc. Lean. (1993) The Contracts of Individual and Organization. Journal of Organizational Behavior, Volume 15 : 1-43.

Rousseau, D.M\& Tijoriwala, Snehal A. (1998) Assessing Psychological Contract : Issues, Altenatives and Measures. Journal of Organizational Behavior. Volume 19, 679-695.

Rousseau, D.M., (2000) Psychological Contract Inventory. Carneige Melloon University, Pittsburg Pensylvania. 
Rousseau, D.M., (1994) Violating Psychological Contract, Not The Exception But The Norm.Journal of Organizational Behavior. DOI : 10.1002/job.4030150306

Rousseau, D.M. (1995). Psychological Contracts in Organizations. Thousand Oaks: Sage.

Ruokolainen, Mervi et al. (2016). Pattern of Psychological Contract and Their Relationship to Employee Well Being and In Role Performance at Work : Longitudinal Evidence from University Employees. The International Journal of Human Resource and Management.ISSN : 0958-5192

Ryff, Carol D. (1989) Happiness is everything, or is it? Explorations on the meaning of psychological well-being.Journal of Personality and Social Psychology, Vol 57(6), 1069-1081

Ryff, D. \& Singer, K. 2006. Know Thyself and Become What You Are : A Eudaimonic Approach to Psychological Well-Being. Journal of Happiness Studies, 9. 13-19.

Shore, Lynn McFarlane \& Tetrick, Lois E. (1994). The Psychological Contract as An Explanatory Framework in the Employment Relationship. Trends in Organizational Behavior, Volume 1. John Wiley and Sons, 91-109.

Shore, Lynn M., \& Barksdale, Kevin.(1998). Examining Degree of Balance and Level of Obligation in the Employment Relationship: a Social Exchange Approach. Journal of Organizational Behavior, 19, 731-744

Sparrow, P.R. (1996). Transition in Psychological Contract : Some Evidence from the Banking Sector. Human Resource Management Journal, 6, 4, 75-92.

Sutton, G., \& Griffin, M. A. (2004). Integrating expectations, experiences, and psychological contract violations: Alongitudinal study of new professionals. Journal of Occupational and Organizational Psychology, 77, 493-514.

Turnley, H. William \& Feldman, Danield C. (2000). Re-examining the Effects of Psychological Contract Violation : Unmet Expectation and Job Disatisfaction as Mediators. Journal of Organization Behaavior. Volume 21, Issue 1, 25-42.

Undang-Undang Republik Indonesia. Nomor 14 Tahun 2005 Tentang Guru dan Dosen.

Vaart, Leoni van der; Linde, Bennie and Cockeran, Marike. (2013). The state of the psychological contract and employees' intention to leave: The mediating role of employee well-being. South African Journal of Psychology 43(3) 356-369. sagepub.co.uk/journalsPermissions.nav DOI: 10.1177/0081246313494154 sap.sagepub.com

Whyte, W. 1956. The Organisation Man. New York: Simon \& Schuster

Wocke, Albert \& Sutherland, Margaret. (2008). The Impact of Employment Equity Regulations on Psychological Contracts in South Africa. International Journal of Human Resource Management. DOI : 10.1080 / 09585190801953525

Zajencyk, Thomas J., et all. (2011). Psychological Contracts and Organizational Identification: The Mediating Effect of Perceived Organizational Support. Springer Science and Business Media. 32:254-281. DOI 10.1007/s12122-0119111-z 
Zhao, H., Wayne S.J, Glibkowski, B.C., Bravo J. (2007). The Impact of Psychological Contract Breach on Work Related Outcomes : a Meta Analysis. Personnel Psychology, 60, 547-680. 